\title{
Comparison of brown trout (Salmo trutta) reared in fresh water and sea water to freshwater rainbow trout (Oncorhynchus mykiss): II. Phosphorus balance
}

\author{
Antoine Dosdat ${ }^{(1)}$, Robert Métailler ${ }^{(2)}$, Elisabeth Desbruyères ${ }^{(3)}$, Christine Huelvan ${ }^{(2)}$ \\ (1) Station de Palavas, IFREMER, 34250 Palavas-les-Flots, France. \\ (2) Laboratoire de Nutrition des Poissons, IFREMER-INRA, BP 70, 29280 Plouzané, France. \\ (3) Laboratoire de Physiologie des Poissons, IFREMER, BP 70, 29280 Plouzané, France.
}

Received Ocbober 31, 1997; accepted December 15, 1997.

\begin{abstract}
Brown trout and rainbow trout (average weight $100 \mathrm{~g}$ ) were reared in fresh water at $12^{\circ} \mathrm{C}$ under the same conditions before transferring brown trout to sea water, in order to compare phosphorus utilisation in both species. Apparent phosphorus availability, orthophosphate excretion and phosphorus accretion in the fish were directly determined. Thus, actual phosphorus mass balance was built. Rainbow trout raised in fresh water had a higher phosphorus retention coefficient (maximum $50 \%$ ) than brown trout reared in fresh water (maximum $45 \%$ ). Transferring brown trout to sea water induced a reduction in phosphorus retention (maximum $39 \%$ ). Orthophosphate excretion, ranging 7-20 mg phosphorus per $\mathrm{kg}$ wet weight per day, represented $10-20 \%$ of ingested phosphorus. Phosphorus availability was lower in brown trout raised in sea water $(65 \%)$ than brown trout raised in fresh water $(76 \%)$. Phosphorus balance measurements showed that 90 to $98 \%$ of phosphorus flow could be accounted for. $(\mathcal{O}$ Ifremer Elsevier, Paris
\end{abstract}

phosphorus intake / digestibility / excretion / Salmo trutta / Oncorhynchus mykiss

Résumé - Comparaison de la truite commune (Salmo trutta) élevée en eau douce et en eau de mer avec la truite arc-en-ciel d'eau douce (Oncorhynchus mykiss): II. Bilan du phosphore. Des truites communes ct des truites arc-cn-cicl ont été ćlevées à $12^{\circ} \mathrm{C}$ dans des conditions strictement identiques, avant le transfert des truites communes en eau de mer, dans le but de comparer l'utilisation du phosphore chez les deux espèces. La disponibilité apparente de phosphore, l'excrétion d'orthophosphate par les poissons, et l'accrétion de phosphore chez ces poissons ont été estimées par mesure directe. Ainsi, les réels bilans de masse ont pu être construits. Les truites arc-en-ciel élevées en eau douce présentent un meilleur coefficient de rétention du phosphore (maximum $50 \%$ ) que les truites communes élevées en eau douce (maximum $45 \%$ ). Le transfert de la truite commune en eau de mer a entraîné une diminution de la rétention du phosphore (maximum $39 \%$ ). L'excrétion d'orthophosphate, de 7 à 20 mg de phosphore par kg de poids vif par jour, représente 10-20\% du phosphore ingéré. La disponibilité du phosphore chez la truite commune était plus faible en eau de mer $(65 \%)$ qu'en eau douce $(76 \%)$. Le rapport entre les entrées et les sorties de phosphore du système d'élevage, compris entre 90 et $98 \%$, montre que l'estimation du bilan de masse est correcte. $\odot$ Ifremer-Elsevier, Paris

phosphore / digestibilité / excrétion / Salmo trutta / Oncorhynchus mykiss 


\section{INTRODUC'TION}

Brown trout (Salmo trutta fario) is a very promising salmonid species, which can withstand the climatic conditions such as high temperature and high salinity prevailing on the southern European coast [28]. French legislation imposes an environmental impact study, to build new fish farms, including an estimation of nutrient loadings [12]. Phosphorus is the second driving element in the eutrophication process in the marine environment after nitrogen [34]. It is also an essential dictary clcment in fish $[33,47,30]$. Salmonid diets usually contain large amounts of fish meal, which generally provide sufficient available phosphorus. Recently, phosphorus content in Atlantic salmon (Salmo salar) and rainbow trout (Oncorhynchus mykiss) diets was reduced in order to limit phosphorus discharge. Unfortunately few data are available regarding the nutritional requirements, cxcretion and metabolism of brown trout $[30,11,12]$. It is not known if phosphorus metabolism in brown trout is similar to other members of the salmonid family, particularly rainbow trout. Phosphorus requirements are relatively well known in rainbow trout $[38,27,43]$. Phosphorus loadings have been studied in rainbow trout farms in both fresh water $[26,48,19]$ and sea watcr $[1,22]$. Only limited information is available for brown trout raised in fresh water [9] and data are totally lacking for brown trout raised in sea water. The objectives of the present study were (1) to compare phosphorus losses and utilisation in both species, held in fresh water, and (2) to determine the influence of sea water on phosphorus utilization of brown trout.

Growth and nitrogen balance have been described in a previous paper [14].

\section{MATERIALS AND METHODS}

\subsection{Experimental design and rearing conditions}

The experiment was organized in four consecutive phases as described previously [14]. Parameters concerning phosphorus were recorded during the same experimental protocol, in exactly the same conditions. Phase 1 was dedicated to the comparison of phosphorus excretion and phosphorus accretion in brown trout and rainbow trout reared in fresh water. During the second phase, the same comparison was made on brown trout during their adaptation to sea water. Seawateradapted brown trout were then compared to the rainbow trout and brown trout maintained in fresh water (phase 3). This latter phase was pursued to determine hourly excretion rate and bioavailability of phosphorus in the same water quality conditions (phase 4).

Rainbow trout (RT) and brown trout (BT) were obtained from the IFREMER-INRA Experimental Station in Sizun (Brittany, France). Fish were sorted and dispatched into twelve indoor $500 \mathrm{~L}$ tanks $(1 \times 1 \times$ $0.5 \mathrm{~m}$ ), supplied with fresh water (FW). Eight tanks were filled with brown trout (BT.FW, average weight $90 \mathrm{~g}$ ) and 4 tanks with rainbow trout (RT.FW, average weight $80 \mathrm{~g}$ ). Fish were hand fed a fixed ration twice daily at 10:00 and 16:00 $\mathrm{h}$ using floating expanded pellets (the rationing and the composition of which are described in [14]) containing $0.93 \%$ total phosphorus, $10 \%$ of which derived from calcium hydrogen phosphate and the remaining from the ingredients. During the whole experiment (including acclimatisation), particular altention was given to feed intake which was recorded at each meal in every tank. Photoperiod was maintained on a 12L:12D (8:00-20:00 h) cycle.

The first phase of the experiment lasted 46 days. The feeding level was fixed at $1 \%$ of the biomass and uneaten pellets were recorded. The second phase began when brown trout in 4 of the 8 tanks were progressively transferred to sea water (SW) over two days by adding thermoregulated $\left(12^{\circ} \mathrm{C}\right)$ filtered sea water. Dead fish were recorded and wcighed every day. At the end of the second phase (day 66) fish were weighed and re-allocated in order to balance the biomass in the tanks, which had previously been altered by differential mortality and growth rates. All rearing conditions were similar, except salinity. The third phase lasted 50 days. Both sea water and fresh water were thermoregulated at $12{ }^{\circ} \mathrm{C}$. During this phase, the ration was fixed at $0.9 \%$ of the biomass. The fourth phase took place when fish were transferred into 3 cylindroconical tanks $\left(1 \mathrm{~m}^{3}\right)$ in order to determine phosphorus availability and to monitor hourly excretion rates. This phase lasted 40 days, including acclimatization to the new tanks. Faeces and water were sampled during the last five days of the phase. In order to cnable correct availability evaluation, the fish were fed once a day and tanks cleaned every day.

\subsection{Sampling of wastes in eff1uent water}

During the first three phases, outflowing water quality was monitored in each tank, including reference tanks with no fish [13]. The sampling runs lasted 5 consecutive days before each weighing: two runs occurred during phase 1 , one run during phase 2 and two runs during phase 3 . Water was sampled through a persistaltic pump and pooled into polypropylene bottles with chloroform as a preservative [13]. Orthophosphate phosphorus $\left(\mathrm{P}-\mathrm{PO}_{4}\right)$ was analysed by the molybdate method [35]. Analyses were conducted using a Technicon ${ }^{(B)}$ Autoanalyser II. This enabled evaluation of average $\mathrm{P}-\mathrm{PO}_{4}$ content of the water on a daily basis. For each tank, the freshwater flow, coming from a water tower, was measured once a day, and seawater flow twice a day before and after every filter cleaning operation.

During the fourth phase, phosphorus availability of the feed was evaluated by using a decantation bottle and chromic oxide as a marker [8]. Faeces were collected with $1000 \mathrm{~mL}$ of supernatant water, over 5 consecutive days, after 7 days of acclimation to the feed, and then frozen $\left(-20^{\circ} \mathrm{C}\right)$. Pooled samples were 
centrifuged $\left(15 \mathrm{~min}, 4{ }^{\circ} \mathrm{C}, 4000 \mathrm{rpm}\right)$ and the phosphorus content of the supernatant and the bottom analysed separately. Pallems of $\mathrm{P}-\mathrm{PO}_{4}$ excretion were monitored using the method described earlier [13].

\subsection{Sampling and chemical analyses of feed, fish and faeces}

Rainbow trout and brown trout were sampled after one day of fasting in two sets at day 0 (5 tish per tank, pooled). On day 46, 66 and 116, 10 fish per tank were sampled and analysed scparately.

Proximate analysis of feed and chemical composition analysis of fish were performed as follows: dry matter after drying $24 \mathrm{~h}$ at $105^{\circ} \mathrm{C}$, total phosphorus as $\mathrm{P}-\mathrm{PO}_{4}$, after total oxidation with sulphuric acid and oxygenated water $\left(\mathrm{H}_{2}-\mathrm{O}_{2}\right)$ by the molybdate method [35]. Phosphorus in the faeces was analysed for both particulate and soluble phases, and chromic oxide in faeces and feed as previously described [5].

\subsection{Data processing and statistical analysis}

In all calculations, ingested feed is given in dry matter. The following parameters were used: $\mathrm{B}=\mathrm{Bio}-$ mass wet weight $(\mathrm{g}) ; \mathrm{Q}=$ water flow rate $\left(\mathrm{L} \cdot \mathrm{h}^{-1}\right)$; $\mathrm{C}=$ orthophosphate concentration $\left(\mathrm{mg} \cdot \mathrm{L}^{-1}\right)$.

Basic data were processed to determine:

(i) Phosphorus retention coefficient

$100 \times$ (Final phosphorus fish content

- Initial phosphorus fish content

Phosphorus intake

(ii) Apparent availability coefficient of Phosphorus (\%) $100-[100 \times(\mathrm{Cr}$.diet/Cr.faeces $) \times($ P.faeces/P.diet $)]$

(iii) Daily excretion rate $\left(\mathrm{mg} \mathrm{P} \cdot \mathrm{kg}^{-1} \cdot \mathrm{day}^{-1}\right)$

(Average outflow concentration - Average outflow concentration of empty tank) $\times \mathrm{Q} \times 24 \mathrm{~B}$

(iv) Hourly excretion rate ( $\mathrm{mg} \mathrm{P} \cdot \mathrm{kg}^{-1} \cdot \mathrm{h}^{-1}$ ), defined in [13] as:

$$
\left(\frac{Q}{1-e^{-Q T / V}}\right) \times\left(C_{t+1}-C_{i}-\left(C_{t}-C_{i}\right) e^{-Q T / V}\right) \times \frac{1}{B}
$$

where $V$ is tank volume, $C_{t}\left(C_{i}\right)$ outflowing (empty tank) concentrations and $T$ time interval.

(v) Phosphorus recovery rate (\%)

$100 \times$ (Final phosphorus fish content + Phosphorus faeces content + Excreted $\mathrm{P}_{-} \mathrm{PO}_{4}$ )

(Initial phosphorus fish content + Phosphorus intake)

Where two factors were analysed, a comparison of the means was carried out using the Student $t$-test, after

Aquat. Living Resour. 11 (1) (1998) testing the homogeneity of the variance in the case of an unbalanced number of tanks (phase 1). One way ANOVA was used in balanced experiments involving three conditions (phase 2 and phase 3), followed by a Newman-Keuls-test for a posteriori classification. When percentage values were to be tested, the $\arcsin V$ transformation was employed.

\section{RESULTS}

\subsection{Orthophosphate phosphorus $\left(\mathrm{P}-\mathrm{PO}_{4}\right)$ excretion}

$\mathrm{P}_{-} \mathrm{PO}_{4}$ excretion rates, expressed in $\mathrm{mg} \mathrm{P} \cdot \mathrm{kg}^{-1} \cdot \mathrm{d}^{-1}$, were lower in RT.FW during phase 2 and 2 (table I). They were similar during phase 3 and 4 . With increasing weight, from phase 1 to phase 3 , excreted $\mathrm{P}_{-} \mathrm{PO}_{4}$ increased in RT.FW ( $\left.\mathrm{F}_{15.4}=43.1, P<0.001\right)$, contrarily to BT.FW $\left(\mathrm{F}_{15.4}=1.74\right.$, not significant $)$. This was also the case when $\mathrm{P}_{-} \mathrm{PO}_{4}$ excretion rates were expressed as a percentage of ingested phosphorus. During adaptation to sea water, brown trout excreted larger amounts $\mathrm{P}_{-} \mathrm{PO}_{4}$, compared to their phosphorus ingestion $(35.6 \%$ instead of $22.4 \%$ in BT.FW). In acclimatised BT.SW, ${\mathrm{P}-\mathrm{PO}_{4}}_{\text {excretion rates were sig- }}$ nificantly lower than in BT.FW (phase 3-run 2 and phase 4).

Excretion profiles (figure 1) confirmed the data obtained by the pooling method during phase 3-run 2 (table I). They show no trend, and no linkage with the feeding or the dark period was noticeable. Maximum excretion rates reached $1.0-1.5 \mathrm{mg} \mathrm{P}_{-} \mathrm{PO}_{4} \cdot \mathrm{kg}^{-1} \cdot \mathrm{h}^{-1}$ in BT.FW.

\subsection{Phosphorus accretion}

RT.FW retained ingested phosphorus in a better way than brown trout under all conditions, although it was not significant in phase 1 due to great variability, and in phase 2 due to the very low value in BT.SW (table II). In RT.FW retained phosphorus reached more than $50 \%$ of the ingested phosphorus. During acclimatisation to sea water, brown trout retained only around $4 \%$ of ingested phosphorus. No significative difference was observed between BT.FW and acclimatised BT.SW.

\subsection{Mass balance}

Monitored output parameters, i.e. faeces phosphorus, $\mathrm{P}_{-} \mathrm{PO}_{4}$ and final whole body phosphorus, represented more than $90 \%$ of total phosphorus input from feed and initial whole body phosphorus content (table II). No particular trend was noticeable. Phosphorus availability varied from 65 to $76 \%$. It was lower in BT.SW. Soluble phosphorus in the faeces represented $15 \%$ of the total faeces content in RT.FW and BT.SW, and $29 \%$ in BT.FW. Phosphorus content in the fish represented $0.32-0.35 \%$ of the whole body wet 


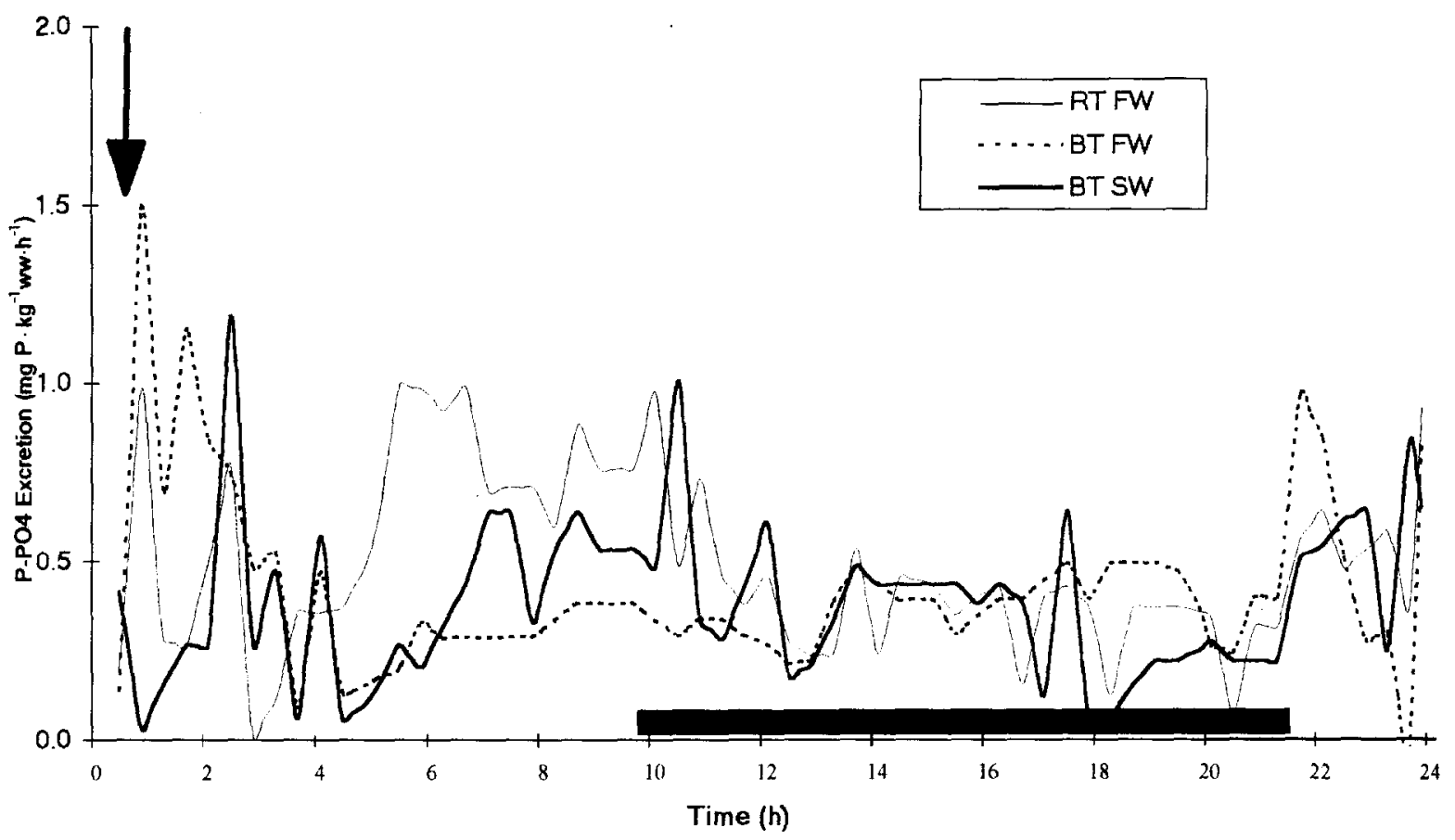

Figure 1. Orthophosphate phosphorus excretion profiles of 50 fish (average weight 300-380 g): RT.FW is rainbow trout in fresh water, BT.FW is brown trout in fresh water and BT.SW is brown trout in sea water. Arrow indicates feeding time. Dark area represents the night period.

Table I. Comparison of orthophosphate phosphorus excretion during the 4 phases of the experiment. Excreted and ingested phosphorus are given in $\mathrm{mg} \mathrm{P} \cdot \mathrm{kg}^{-1} \cdot \mathrm{d}^{-1}$. Values for excretion in phase 4 are recalculated from hourly excretion rates. For each run, the date of which is given, values in the same column not sharing a common superscript are different at the level $P<0.05$. Significance of Student $t$ - $(t$-test) and ANOVA $(F)$ tests are given at: $* P<0.05, * * P<0.01, * * * P<0.005$, NS: not significant.

\begin{tabular}{|c|c|c|c|c|c|c|c|c|}
\hline & & Fish & $\mathrm{Nb}$ tank & $\begin{array}{c}\text { Average } \\
\text { weight (g) }\end{array}$ & $\begin{array}{l}\text { Phosphorus } \\
\text { intake }\end{array}$ & $\begin{array}{c}\text { Excreted } \\
\mathrm{P}_{-} \mathrm{PO}_{4}\end{array}$ & $\begin{array}{l}t \text {-test for } \\
\text { ANOVA }\end{array}$ & $\begin{array}{c}\text { Excr. } \mathrm{P}-\mathrm{PO}_{4} \\
\text { Ingested } \mathrm{P}(\%)\end{array}$ \\
\hline Phase 1 & $\begin{array}{c}\text { Run } 1 \\
\text { Dec. } 12 \rightarrow \text { Dec. } 16\end{array}$ & $\begin{array}{l}\text { RT.FW } \\
\text { BT.FW }\end{array}$ & $\begin{array}{l}4 \\
8\end{array}$ & $\begin{array}{l}112.5 \\
108.9\end{array}$ & $\begin{array}{l}74.9 \\
79.1\end{array}$ & $\begin{array}{r}6.7 \pm 1.4 \\
15.3 \pm 1.6\end{array}$ & $\begin{array}{c}t=8.9 \\
* * * *\end{array}$ & $\begin{array}{r}9.0 \\
19.3\end{array}$ \\
\hline Phase 1 & $\begin{array}{c}\text { Run } 2 \\
\text { Jan. } 9 \rightarrow \text { Jan. } 13 \\
\end{array}$ & $\begin{array}{l}\text { RT.FW } \\
\text { BT.FW }\end{array}$ & $\begin{array}{l}4 \\
8\end{array}$ & $\begin{array}{l}151.1 \\
136.8 \\
\end{array}$ & $\begin{array}{l}69.7 \\
71.9 \\
\end{array}$ & $\begin{array}{r}6.9 \pm 0.8 \\
16.3 \pm 2.6 \\
\end{array}$ & $\begin{array}{c}t=7.0 \\
* * * *\end{array}$ & $\begin{array}{r}9.9 \\
22.7 \\
\end{array}$ \\
\hline Phase 2 & $\begin{array}{c}\text { Run } 1 \\
\text { Jan. } 16 \rightarrow \text { Jan. } 20\end{array}$ & $\begin{array}{l}\text { RT.FW } \\
\text { BT.FW } \\
\text { BT.SW }\end{array}$ & $\begin{array}{l}4 \\
4 \\
4\end{array}$ & $\begin{array}{l}158.7 \\
142.8 \\
139.1\end{array}$ & $\begin{array}{l}84.5 \\
87.9 \\
35.9\end{array}$ & $\begin{array}{r}7.9 \pm 1.5^{\mathrm{h}} \\
19.7 \pm 2.1^{\mathrm{c}} \\
12.8 \pm 1.8^{\mathrm{b}}\end{array}$ & $\begin{array}{c}F=45.0 \\
* * *\end{array}$ & $\begin{array}{r}9.4 \\
22.4 \\
35.6 \\
\end{array}$ \\
\hline Phase 3 & Feb. $27 \rightarrow$ March 3 & $\begin{array}{l}\text { RT.FW } \\
\text { BT.FW } \\
\text { BT.SW }\end{array}$ & $\begin{array}{l}4 \\
4 \\
4\end{array}$ & $\begin{array}{l}227.7 \\
193.5 \\
179.4\end{array}$ & $\begin{array}{l}75.2 \\
76.6 \\
61.4\end{array}$ & $\begin{array}{l}12.6 \pm 4.6 \\
14.2 \pm 2.9 \\
14.1 \pm 2.4\end{array}$ & $\begin{array}{c}F=0.9 \\
\text { NS }\end{array}$ & $\begin{array}{l}16.7 \\
18.5 \\
22.9\end{array}$ \\
\hline Phase 3 & $\begin{array}{c}\text { Run } 2 \\
\text { Mar. } 20 \rightarrow \text { Mar. } 24\end{array}$ & $\begin{array}{l}\text { RT.FW } \\
\text { BT.FW } \\
\text { BT.SW } \\
\end{array}$ & $\begin{array}{l}4 \\
4 \\
4 \\
\end{array}$ & $\begin{array}{l}282.5 \\
229.3 \\
207.8 \\
\end{array}$ & $\begin{array}{l}68.4 \\
70.1 \\
67.9 \\
\end{array}$ & $\begin{array}{l}14.7 \pm 1.0^{\mathrm{b}} \\
14.6 \pm 1.2^{\mathrm{b}} \\
10.3 \pm 1.5^{\mathrm{a}}\end{array}$ & $\begin{array}{c}F=15.5 \\
* * *\end{array}$ & $\begin{array}{l}21.4 \\
20.8 \\
15.2 \\
\end{array}$ \\
\hline Phase 4 & $\begin{array}{c}\text { Run } 1 \\
\text { May } 1 \rightarrow \text { May } 2\end{array}$ & $\begin{array}{l}\text { RT.FW } \\
\text { BT.FW } \\
\text { BT.SW }\end{array}$ & $\begin{array}{l}1 \\
1 \\
1\end{array}$ & $\begin{array}{l}380 \\
308 \\
323\end{array}$ & $\begin{array}{l}64.1 \\
65.7 \\
63.3\end{array}$ & $\begin{array}{r}12.4 \\
11.3 \\
9.5\end{array}$ & & $\begin{array}{l}19.3 \\
17.2 \\
15.0\end{array}$ \\
\hline
\end{tabular}

RT, rainbow trout; BT, brown trout; FW, fresh water; SW, sca watcr.

weight (1.27-1.40\% dry matter). A two way ANOVA on species and size showed that phosphorus content increased in RT.FW, from 0.310 to $0.348 \%$, and BT.FW, from 0.340 to $0.354 \%\left(F_{1,12}=9.1, P<0.05\right)$, from phase 1 to phase 3 , but there was no inter-specific difference $\left(F_{1.12}=3.2\right)$. During phase 3, phosphorus content in BT.SW increased from 0.33 to $0.37 \%$ of the whole body weight. 
Table II. Phosphorus mass balance. All values, except recovery rate, are given in proportion of feed intake (mean \pm standard deviation). Recovery rate is given as percentage of feed phosphorus intake + initial fish phosphorus content. For each phase, values in the same column not sharing a common superscript are different at the level $P<0.05$. Significance of Student $(t)$ and ANOVA $(F)$ tests are given at: NS non significant, $*<<0.05$, $* * P<0.01, * * * P<0.005$. For phase 2 and phase 3, wasted $\mathrm{P}_{-} \mathrm{PO}_{4}$ is the average of the weighted means of two runs, for four tanks.

\begin{tabular}{|c|c|c|c|c|c|c|c|c|c|c|}
\hline & Fish & $\mathrm{Nb} \operatorname{tank}$ & $\begin{array}{c}\text { Retained } \\
\text { phosphorus }\end{array}$ & $\begin{array}{l}t \text {-test or } \\
\text { ANOVA }\end{array}$ & $\begin{array}{c}\text { Wasted in faeces } \\
\text { (= } 100-\text { Apparent } \\
\text { Digestibility } \\
\text { Coefficient) }\end{array}$ & $\begin{array}{c}\text { Wasted as } \\
\mathrm{P}_{-} \mathrm{PO}_{4}\end{array}$ & $\begin{array}{l}t \text {-test or } \\
\text { ANOVA }\end{array}$ & $\begin{array}{l}\text { Soluble } \\
\mathrm{P}_{-} \mathrm{PO}_{4} \\
\text { (\% total } \\
\text { wastes) }\end{array}$ & $\begin{array}{l}\text { Recovery } \\
\text { rate } \\
(\%)\end{array}$ & $\begin{array}{l}t \text {-test or } \\
\text { ANOVA }\end{array}$ \\
\hline Phase 1 & $\begin{array}{l}\text { RT.FW } \\
\text { BT.FW }\end{array}$ & $\begin{array}{l}4 \\
8\end{array}$ & $\begin{array}{l}47.8 \pm 5.9 \\
38.8 \pm 7.5\end{array}$ & $\begin{array}{c}t=1.9 \\
\mathrm{NS}\end{array}$ & $\begin{array}{l}25.2 \\
23.2\end{array}$ & $\begin{array}{r}9.5 \pm 0.5 \\
20.0 \pm 1.1\end{array}$ & $t=16.6$ & $\begin{array}{l}27.4 \\
46.3\end{array}$ & $\begin{array}{l}90.1 \pm 3.4 \\
90.4 \pm 3.9\end{array}$ & $\begin{array}{c}t=0.1 \\
\mathrm{NS}\end{array}$ \\
\hline Phase 2 & $\begin{array}{l}\text { RT.FW } \\
\text { BT.FW } \\
\text { BT.SW }\end{array}$ & $\begin{array}{l}4 \\
4 \\
4\end{array}$ & $\begin{array}{r}38.9 \pm 5.9^{\mathrm{b}} \\
29.6 \pm 5.1^{\mathrm{b}} \\
3.8 \pm 7.7^{\mathrm{a}}\end{array}$ & $F=32.9$ & $\begin{array}{l}25.2 \\
23.2 \\
34.7\end{array}$ & $\begin{array}{r}9.4 \pm 1.5^{\mathrm{a}} \\
22.4 \pm 2.2^{\mathrm{h}} \\
35.6 \pm 6.4^{\mathrm{c}}\end{array}$ & $\begin{array}{c}F=38.2 \\
* * *\end{array}$ & $\begin{array}{l}27.2 \\
49.1 \\
49.6\end{array}$ & $\begin{array}{l}91.4 \pm 1.1^{\mathrm{a}} \\
93.2 \pm 1.8^{\mathrm{b}} \\
94.5 \pm 1.3^{\mathrm{b}}\end{array}$ & $\begin{array}{c}F=5.2 \\
*\end{array}$ \\
\hline Phase 3 & $\begin{array}{l}\text { RT.FW } \\
\text { BT.FW } \\
\text { BT.SW }\end{array}$ & $\begin{array}{l}4 \\
4 \\
4\end{array}$ & $\begin{array}{l}55.4 \pm 4.5^{\mathrm{b}} \\
43.2 \pm 4.4^{\mathrm{a}} \\
44.8 \pm 4.9^{\mathrm{a}}\end{array}$ & $\begin{array}{c}F=8.33 .8 \\
* *\end{array}$ & $\begin{array}{l}25.2 \\
23.2 \\
34.7\end{array}$ & $\begin{array}{l}18.7 \pm 1.6 \\
19.3 \pm 2.0 \\
19.2 \pm 1.7\end{array}$ & $\begin{array}{c}F=0.1 \\
\text { NS }\end{array}$ & $\begin{array}{l}42.6 \\
45.3 \\
35.6\end{array}$ & $\begin{array}{l}99.5 \pm 2.7^{\mathrm{b}} \\
92.3 \pm 1.3^{\mathrm{a}} \\
99.2 \pm 3.6^{\mathrm{b}}\end{array}$ & $\begin{array}{c}F=5.2 \\
*\end{array}$ \\
\hline
\end{tabular}

RT, rainbow trout; BT, brown trout; FW, fresh water; SW, sea water

\section{DISCUSSION}

Fish meal phosphorus availability ranges $66-80 \%$ in rainbow trout $[39,24]$. Ritchie and Brown [42] stated $50 \%$ for herring meal, the major ingredient of the diet. Phosphorus availability is more dependant on species than protein: availability decreases to $13-33 \%$ in carp. In our experiment, dietary phosphorus was mainly provided by Norwegian fish meal (Norseamink ${ }^{\circledR}$ ). Only $10 \%$ of the dietary phosphorus came from mono-calcium phosphate, the availability of which is $94 \%$ in rainbow trout [39]. The phosphorus content of the faeces was $1.5-2.0 \%$ (dry inatter) compared to $0.93 \%$ in the diet: recorded dietary phosphorus availability was lower than the digestibility of the dry matter of the diet. Phosphorus availability increased with increasing size in Atlantic salmon [44]. This could explain the differences in recovery rate observed during phase 1 (120 g fish) and phase 3 (200-250 g fish), as phosphorus availability was determined on 300-380 $\mathrm{g}$ fish. This may have led to an underestimation in smaller fish. Using the same diet and the same methodology in turbot, availability was determined at $70 \%$ and was independent of ration size [46].

Faecal phosphorus losses represented 55-73\% of the total wastes. This ratio is in agreement with other workers who found that phosphorus discharge was mainly under the form of settelable solids [15, 40, 9, 22]. Phosphorus availability appeared to be lower in BT.SW than in BT.FW, though sodium is reported to facilitate active phosphorus secondary transport by $\mathrm{Na}^{+}-\mathrm{K}^{+}$ATP-ase in the eel [6] and carp [36] intestinal epithelial cells. Absorption of more water containing a greater quantity of sodium and phosphate (sea water contained $0.010 \mathrm{mg} \cdot \mathrm{L}{ }^{1} \mathrm{P}-\mathrm{PO}_{4}$ when fresh water contained $0.005 \mathrm{mg} \cdot \mathrm{L}^{-1}$ ) may be an antagonist of dietary phosphorus absorption. As vitamin $D$ is known to enhance net phosphorus absorption in rats $[7,32]$ and to increase renal phosphate reabsorption in eels [18], the effect of vitamin $D_{3}$ enhancement in diets for brown trout reared in sea water needs to be investigated.
In the experiment, the phosphorus content in the fish increased when the fish grew. Phosphorus content in the fish is known to decrease with increasing size [44, 30]. Phosphorus is mainly represented in bones and scales that grow more slowly than the whole fish. At the end of the experiment, $\mathrm{P}$ content in the fish $(0.32$ $0.35 \%$ of the wet weight in $150-300 \mathrm{~g}$ fish) was lower than what was estimated in $650 \mathrm{~g}$ rainbow trout $(0.375 \%)$ [16]; in $200 \mathrm{~g}$ rainbow trout, where phosphorus content was estimated between 0.38 and $0.45 \%$ of the wet weight $[44,22,43]$, in $1 \mathrm{~g}$ fish (46\% by [38]). [10] estimated phosphorus content in juvenile $\Lambda$ tlantic salmon (Salmo salar) at $0.38 \%$ and [2] at $0.55-0.60 \%$ in $1 \mathrm{~g}$ fish. No difference was noticeable in phosphorus content between rainbow trout and brown trout in our study. This increasing phosphorus content may be due to the previous history of the fish before starting the experiment.

It could also be due to a diet phosphorus content above the requirement which tend to increase $P$ content in the verbebrae [38]. Phosphorus requirement does not vary with salinity in Atlantic salmon [25, 31]. Brown trout phosphorus requirement is not precisely known, but is probably within the range of those for other salmonids. Oringo and Takeda [38] estimated the need of rainbow trout for available phosphorus at $0.65 \%$ of the diet in very small fish, which seems to have higher requirement than older ones [17], and at 0.55-0.65\% in larger fish [41]. Weissman et al. [48] recommended $0.5 \%$ in $250 \mathrm{~g}$ rainbow trout, when it was $0.6 \%$ in 100 $\mathrm{g}$ Atlantic salmon reared in sea [31]. In our study, available phosphorus content was $0.70 \%$ of the diet in RT.FW and BT.FW and 0.60 in BT.SW, i.e. superior or equal to the known requirements for big fish. These data are more relevant when expressed as a function of growth and food/gain ratio. A requirement of $5.5 \mathrm{~g}$ available phosphorus by $1 \mathrm{~kg}$ of wet weight gain was found in $250 \mathrm{~g}$ rainbow trout [48], and $4.6 \mathrm{~g}$ in $200 \mathrm{~g}$ fish [43]. In our study, the production of one $\mathrm{kg} \mathrm{RT.FW}$ corresponded to the ingestion of $5.7 \mathrm{~g}$ of available 
phosphorus and respectively 7.3 and $6.8 \mathrm{~g}$ in BT.FW and BT.SW, far more than found by these authors.

The phosphorus retention coefficient was higher in rainbow trout than in brown trout, as was observed for nitrogen [14]. It has been reported to be very high $(67 \%)$ in $35 \mathrm{~g}$ rainbow trout [27]. A relation was found between feed quality and phosphorus retention, ranging from 34 to $40 \%$ in $250 \mathrm{~g}$ rainbow trout [29]. No difference was observed by [9] between rainbow trout and brown trout, but two different diets were used [9]. No difference appeared in retention between BT.FW and acclimated BT.SW. A lower recovery rate in BT.FW could explain why lower phosphorus losses were not correlated to a higher retention rate. During adaptation to sea water (phase 2), phosphorus retention was very low in brown trout $(13 \%$ of average value in fresh water), comparable to lipid retention during the same period, but lower than nitrogen retention. During adaptation to sea water, additional energy mobilisation, inducing a higher lipid utilisation, seemed also to mobilise phosphorus, probably through $\beta$-oxidation, before it could be settled in the bones, which is a very slow process [30]. The increase in the relative orthophosphate excretion at that time seemed to confirm this hypothesis.

In all vertebrates, phosphate is only excreted through the kidney [4]. This organ has a specific role in divalent ion excretion and has a very different function in sea water or in fresh water. In fresh water, the major role of the kidney is to excrete excess water and to retain salts. In sea water, where fish drink water to compensate for loss through the skin, the kidney extrudes divalent ions $\left(\mathrm{Mg}^{2+}\right)$ and $\mathrm{SO}_{4}^{2-}$ and $\mathrm{PO}_{4}^{2-}$ and conserves water [37]. During acclimatisation to sea water, brown trout showed high phosphate excretion when compared to ingested phosphorus. In sea water, urine flow is one tenth of that in fresh water [21]. In other words, phosphate concentration in urine increased very quickly during that period, due to active secretion in the tubule $\{4,23\rfloor$. T'his phosphorus loss may be due to higher ATP consumption linked to the energetic cost of adaptation and higher seawater phosphate absorption through the digestive tract. After the acclimatisation period of 3 weeks, phosphate excretion by BT.SW decreased to a significativly lower level than in fresh water but not before 1.5 months. This revealed that brown trout were not totally acclimatised after 1.5 months in sea water. The consecutive lower phosphate excretion observed in BT.SW is probably linked to the lower bioavailability of dietary phosphorus. In RT.FW, phosphate excretion increased continuously. Rainbow trout (100 g wet weight) excreted $10 \mathrm{mg} \mathrm{P} \cdot \mathrm{kg}^{-1} \cdot \mathrm{d}^{-1}$ more than BT.FW. This difference was comparable to the difference in retained phosphorus, which could explain differences in excreted phosphorus, given that recovery rates were similar in both cases $(90 \%)$. The missing $10 \%$ could indicate that a greater amount of organic phosphorus is excreted in young fish. This is confirmed by the fact that total soluble phosphorus in the faeces represented around $20 \%$ of settleable phosphorus, allowing some organic phosphorus to be wasted in outflowing water.

The excreted phosphate to faeces phosphorus ratio was greater than reported previously in rainbow trout $[15,22]$, and in brown trout [9]. This may be due to a lower phosphorus faecal waste coming from the higher phosphorus availability and the higher phosphorus content of the diet used in our study. In fact, only $5 \mathrm{~g}$ per $\mathrm{kg}$ feed were available in [9], compared to $9.7 \mathrm{~g} \cdot \mathrm{kg}^{-1}$ feed in our experiment, for the same amount of un-available phosphorus $\left(3 \mathrm{~g} \cdot \mathrm{kg}^{-1}\right)$. Recent works [27], cited $2.0 \mathrm{~g} \mathrm{P}-\mathrm{PO}_{4}$ per $\mathrm{kg}$ wet weight gain were excreted by rainbow trout, and others measured 6-7 g $\mathrm{P}_{-} \mathrm{PO}_{4}$ per $\mathrm{kg}$ wet weight gain [29]. In our study, excreted $\mathrm{P}^{-\mathrm{PO}_{4}}$ was lower, reprcsenting $1.5 \mathrm{~g}$ per $\mathrm{kg}$ wet weight gain in RT.FW (respectively 1.9 and 2.1 in BT.FW and BT.SW). It appears that some progress is conceivable in diet quality [20], particularly through the reduction of the bone content (bones contain $5 \%$ phosphorus) in fish meal and the substitution of fish meal by other ingredients containing less phosphorus.

Phosphate excretion profiles showed no daily trends and seemed independent of feeding. Conversely, phosphate discharge in sea-bass was affected by the meal time [3]. No phosphate excretion was observed in turbot [46]. Orthophosphate excretion in rainbow trout and brown trout remained 10 fold lower than ammonia nitrogen excretion. It seems that phosphate excretion may have specific characteristics among the teleosts where phosphorus metabolism is not as well known than nitrogen metabolism.

Mass balance recovery rate was high during phase 3, contrary to nitrogen wherc rccovery rate never exceeded $93 \%$ [14]. Such high ratios were obtained by monitoring total phosphorus [16]. It was lower during phase 1 where, added to previous interpretations (under estimation of digestibility, organic phosphate excretion), some metabolites and/or other wastes (scales) could have been not evaluated. Metaphosphate excretion cannot be advocated [36]. Nevertheless, during phase 2 , only $73 \%$ of the phosphorus intake was recovered. The fate of the $27 \%$ missing is still to be determined precisely.

These results tend to demonstrate that, with respect to environmental impact assessment, rainbow trout uses phosphorus in better way than brown trout, by retaining more of the ingested phosphorus. The consequence is potentially a higher phosphorus wastage in the environment for brown trout. For bigger fish, that represents the bulk of the biomass in fish farms, it is through the organic phosphorus in the faeces, under solid and soluble forms. 


\section{Acknowledgements}

The authors thank Drs S. Kaushik and D. Coves for very helpful comments on the manuscript. This work was a part of the "Environmental impact of aquaculture" Programme of IFREMER.

\section{REFERENCES}

[1] Ackefors H., Enell M., Discharge of nutrients from Swedish fish farming to adjacent sea areas, Ambio 19 (1990) 28-35.

[2] Asgard T., Shearer K.D., Dietary phosphorus requirement of juvenile Atlantic salmon, Salmo salar L., Aquac. Nutr. 3 (1997) 17-23.

[3] Ballestrazzi R., Lanari D., D'Agaro E., Mion A., The effect of dietary protein level and source on growth, body composition, total ammonia and reactive phosphate excretion of growing sea-bass (Dicentrarchus labrax), Aquaculture 127 (1994) 127-206.

[4] Bijvoet O.L.M., Reitsma P.H., Phylogeny of renal phosphate transport in the vertebrates, Adv. Exp. Med. Biol. 81 (1977) 41-53.

[5] Bolin D.W., King R.P., Klostermann E.W., A simplified method for the determination of chronic oxide $\left(\mathrm{Cr}_{2} \mathrm{O}_{3}\right)$ when used as an index substance, Science 116 (1952) 634-635.

[6] Brichon G., L'absorption du phosphore par l'intestin de l'anguille (Anguilla anguilla L.) I. Mise en évidence et caractères du transport in vitro de l'ion phosphate chez. l'anguille d'eau douce, C.R. Soc. Biol. 167 (1973) $1142-1145$.

[7] Chen T.C., Castillo L., Korycka-Dahl M., de Luca H.F., Role of vitamin D metabolistes in phosphate transport of rat intestine, J. Nutr. 104 (1974) 1056-1060.

[8] Cho C.Y., Slinger S.J., Bayley H.S., Bioenergetics of salmonid fishes: energy intake, expenditure and productivity, Comp. Biochem. Physiol. 73B (1982) 25-41.

[9] Cho C.Y., Hynes J.D., Wood K.R., Yoshida H.K., Quantification of fish culture wastes by biological (nutritional) and chemical (limnological) methods; the development of high nutrient dense (HDN) diets, in: Cowey C.B., Cho C.Y. (eds), Proc. 1st Int. Symp. Nutritional strategies in management of aquaculture waste and Aquaculture Waste, University of Guelph, Guelph, Ontario, Canada, 1991, 37-50.

[10] Crampton V., How to control phosphorus level, Fish Farmer, July/August (1987) 38-39.

[11] Dosdat A., L'excrétion chez les poissons téléostéens. II. Le phosphore, Piscic. Fr. 109 (1992) 18-29.

[12] Dosdat A., Merceron M., Duret J., Kempf M., Fish farming regulation with reference to environmental problems in France, Proc. Workshop on Fish farm effluents and their control in E.C. countries, Hamburg, 23-25 Nov. 1992, 88-92.

[13] Dosdat A., Gaumet F., Chartois H., Marine aquaculture effluent monitoring: methodological approach to the evaluation of nitrogen and phosphorus excretion by fish, Aquac. Eng. 14 (1994) 59-84.
[14] Dosdat A., Métailler R., Desbruyères E., Huelvan C., Comparison of brown trout (Salmo trutta) reared in fresh water and sea water to freshwater rainbow trout (Oncorhynchus mykiss): I. Growth and nitrogen balance, Aquat. Living Resour. 10 (1997) 157-167.

[15] Enell M., Lof J., Environmental impact of aquaculture Sedimentation and nutrient loadings from fish cage culture farming, Vatten 39 (1983) 364-375.

[16] Eskelinen P., The phosphorus balance of rainbow trout, Can. Transl. Fish. Aquat. Sci. 5274, 13 p. (from Vessihallituksen monistesarja 241 (1986) 33-42, 1984; in Finnish).

[17] Eya J.C., Lovell R.T., Available phosphorus requirement of food-size channel catfish (Ictalurus punctatus) fed practical diets in ponds, Aquaculture 154 (1977) 283-292.

[18] Fenwick J.C., Vermette M.G., Vitamine $D_{3}$ and the renal handling in American eels, Fish, Physiol. Biochem. 7 (1989) 351-358.

[19] Foy R.H., Rosell R., Loadings of nitrogen and phosphorus from a Northern Ireland fish farm, Aquaculture 96 (1991) 17-30.

[20] Gavine F.M., Phillips M.J., Murray A., Influence of improved feed quality and food conversion ratios on phosphorus loadings from cage culture of rainbow trout, Oncorhynchus mykiss (Walbaum), in freshwater lakes, Aquacult. Res. 26 (1995) 481-495.

[21] Hickman C.P., 'Trump B.F., The kidney, in: Hoar W.S., Randall D.J. (eds), Fish Physiology, Vol. 1, Academic Press, 1969, pp. 91-239.

[22] Holby O., Hall P.O.J., Chemical fluxes and mass balances in a marine fish cage farm. II. Phosphorus, Mar. Ecol. Prog. Ser. 70 (1991) 263-272.

[23] Kakuta I., Namba K., Uematsu K., Takaba M., Murachi S., Changes in urine properties of cultured red sea bream exposed to dilute sea water, Nippon Suisan Gakkaishi 58 (1992) 1465-1469.

[24] Kaushik S.J., Nutrition et alimentation des poissons et contrôle des déchets piscicoles, Piscic. Fr. 101 (1990) 14-23.

[25] Ketola H.G., Requirement of Atlantic salmon for dietary phosphorus, Trans. Am. Fish. Soc. 104 (1975) 548-551.

[26] Ketola H.G., Mineral nutrition: effects of phosphorus in trout and salmon feeds on water pollution, in: Nutrition and feeding in fish, Academic Press, London, 1985, pp. 465-473.

[27] Ketola H.G., Richmond M.E., Requirement of rainbow trout for dietary phosphorus and its relationship to the amount discharged in hatchery effluents, Trans. Am. Fish Soc. 123 (1994) 587-594. 
[28] Krieg F., Quillet E., Chevassus B., Brown trout, Salmo trutta L.: a new species for intensive marine aquaculture, Aquac. Fish Manage. 23 (1992) 557-566.

[29] Lanari D., D'Agaro E., Ballestrazzi R., Effect of dietary DP/DE ratio on apparent digestibility, growth and nitrogen and phosphorus retention in rainbow trout, Oncorhynchus mykiss (Walbaum), Aquac. Nutr. 1 (1995) 105-110.

[30] Lall S.P., Digestibility, metabolism and excretion of dietary phosphorus in fish, in: Proc. 1st Int. Symp. Nutritional strategies in management of aquaculture waste and Aquaculture Waste, Cowey C.B., Cho C.Y. (eds), University of Guelph, Guelph, Ontario, Canada, 1991, pp. 21-36.

[31] Lall S.P., Bishop F.J., Studies on mineral and protein utilization by Atlantic salmon (Salmo salar) grown in sea water, Fish Mar. Serv. Tech. Rep. 688 (1977) 1-16.

[32] Lee D.B.N., Walling M., Brautbar N., Intestinal phosphate absorption: influence of vitamin $D$ and non vitamin D factors, Am. J. Physiol. 13 (1986) 369-373.

[33] Lovell R.T., Dietary phosphorus requirement of channel catfish (Ictalurus punctatus), Trans. Am. Fish Soc. 107 (1978) 617-621.

[34] Massik Z., Costello M.J., Bioavailability of phosphorus in fish farm cffluents to freshwater phytoplankton, Aquac. Res. 26 (1995) 607-616.

[35] Murphy J., Riley J.P., A modified single solution method for the determination of phosphate in natural waters, Anal. Chim. Acta 27 (1962) 31-36.

[36] Nakamura Y., Sodium-dependent absorption of inorganic phosphate by the carp intestine, Comp. Biochem. Physiol. 80A (1985) 437-439.

[37] Nishimura H., Imai M., Control of renal function in freshwater and marine teleosts, Federation Proc. 41 (1982) 2355-2360.
[38] Ogino C., Takeda H., Requirements of rainbow trout for dietary calcium and phosphorus, Bull. Jpn. Soc. Sci. Fish. 44 (1978) 1019-1022.

[39] Ogino C., Takeuchi L., Takeda H., Watanabe T., Availability of dietary phosphorus in carp and rainbow trout, Nippon Suisan Gakkaishi 45 (1979) 1527-1532.

[40] Phillips M.J., Beveridge M.C.M., Muir J.F., Waste output and environmental effects of rainbow trout cage culture, ICES F:21, 1985, $17 \mathrm{p}$.

[41] Reinitz G.L., Orme L.E., Hitzel F.N., Phosphorus requirement for rainbow trout, Feedstuffs (1978) 50, 18.

[42] Richie M., Brown P.B., Availability of phosphorus from feedstuffs fed to rainbow trout, Oncorhynchus mykiss, Aquaculture 142 (1997) 269-282.

[43] Rodehutscord M., Response of rainbow trout (Oncorhynchus mykiss) growing from 50 to $200 \mathrm{~g}$ to supplemental dibasic sodium phosphate in semi-purified diet, J. Nutr. 126 (1996) 324-331.

[44] Shearer K.D., Changes in elemental composition of hatchery-reared rainbow trout, Salmo gairdneri, associated with growth and reproduction, Can. J. Fish Aquat. Sci. 41 (1984) 1592-1600.

[45] Stigebrand A., Modellberakningar av en fiskodings mijobelastning, Niva, 1986, $28 \mathrm{p}$.

[46] Tétu N., Utilisation de l'azote, du phosphore et de la matière organique par le juvénile de turbot (Scophthalmus maximus L.), Thèse dr. Brest, 1996, 105 p.

[47] Watanabe T., Murakami A., Takeuchi L., Nose T., Ogino C., Requirements of chum salmon held in fresh water for dietary phosphorus, Bull. Jpn. Soc. Sci. Fish 46 (1980) 361-367.

[48] Weismann D., Scheid H., Pfeffer E., Water pollution with phosphorus of dietary origin by intensively fed rainbow trout (Salmo gairdneri Rich.), Aquaculture 69 (1988) 263-270. 